\title{
生物多様性情報を地図化する
}

\author{
中静 透* \\ 東北大学生命科学研究科 $\bar{\top}$ 980-8578 宮城県仙台市青葉区荒巻字青葉 6-3
}

\section{Mapping biodiversity information}

Tohru Nakashizuka*

Graduate School of Life Sciences, Tohoku University, 6-3 Aoba, Aramaki,

Aoba-ku, Sendai, 980-8578 Japan

はじめに

2010 年に名古屋市で生物多様性条約の第 10 回締 約国会議（COP10）が開催され，それに合わせて， Global biodiversity Outlook 3 （GBO3）が公表された (Secretariat of the Convention on Biological Diversity 2010）。その報告は,「2010年までに生物多様性の減 少スピードを顕著に低下させる」という 2010 年目標 が達成できなかったという悲観的なものであった。 この時，ほぼ同時に日本でも，生物多様性総合評価 （JBO）が行われ，日本の状況も整理された（環境省・ 生物多様性総合評価検討委員会 2010)。このような 生物多様性に関する評価を行う作業を行う上での問 題点の一つに，生物多様性に関する定量的データが 少ないこと，とくに地理情報化されていないことが 取り上げられた，そのため, JBO の中でもエキスパー トジャッジという，苦し紛れの手法による評価も少 なくなかった。

一方で, 近年は生息地や潜在的分布の分析などに 関するさまざまな手法が開発され，多くの種の分布 条件の解明やメタアナリシスが行われるようになっ てきた（Franklin 2010）。種の分布だけでなく, InVEST のような生態系サービスを地図化するツー ルも発展してきた（Kareiva et al. 2012）。2012 年に設 立された Intergovernmental science-policy Platform on Biodiversity and Ecosystem Services（iPBES）でも，生 態系サービスのアセスメントが重要な位置を占めて

*連絡先 : toron@m.tohoku.ac.jp

受付 : 2014 年 12 月 10 日/受理 : 2014 年 12 月 10 日
いる。

GB3 による 2010 年目標の評価を受けて愛知目標 が合意され，2014 年 10 月の COP12では，その中間 評価として，GBO4 が公表された（Secretariat of the Convention on Biological Diversity 2014). GBO3 と比 心゙，かなり定量的な情報が充実した報告書になって おり，2020 年までの目標達成をできるだけ定量的に 評価しようという方向性が示されていると思う.

日本でも，JBOの問題点や新しい研究手法の開発 状況を背景に, 生物多様性情報を地図化しようとす る動きが明確になってきており, 現時点の情報を 使って可能な情報の地図化が行われた（自然環境研 究センター 2012). また, 生態系サービスについて も地図化が行われるようになった（地球環境戦略研 究機関・いであ株式会社 2014)。このような, 生物 多様性の地理情報化の最先端を紹介することは，こ の分野の研究者にとっても得るところが大きいと考 える。

\section{特集の構成}

こうした流れをうけて,この特集では 4 つの論文 を書いていただいた．環境省が 1988 年から行ってき た自然環境基礎調査データは, さまざまな情報を含

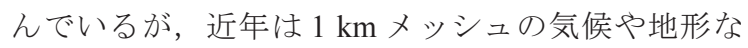
どのデータセットと一緒に解析が可能になってき た。 それを用いた, 群集, 群落レベルの潜在的分布 域について鎌田ほか（2014）に，個々の種の分布を 地図化する作業を実際に行った名取ほか（2014）に は，その作業を通じて明らかとなった問題点をお願 
いした.さらに，個々の種の分布が地理データとし て扱えるということになると，保全すべき地域の優 先度を評価できる。そうした評価手法については, 角谷ほか（2014）にお願いした。さらに,生態系サー ビスに関しては，庄山（2014）にお願いしている.

こうした方向の成果は, 生物多様性の保全や利用 に関して大きな利用可能性がある. 生物多様性の地 域戦略など，自治体などの政策支援にはもちろん， 環境アセスメントなどにも有用である。おりしも， 2011 年に環境影響評価法が改正され，計画段階から の環境影響評価が行われるようになったが，その際 には既存の生物多様性や生態系に関する情報が重要 な役割を果たす。基礎的研究としても，こうした手 法の発達により, よりマクロな視点での解析が進む と考えられる。

\section{引用文献}

地球環境戦略研究機関・いであ株式会社. 2014. 平成 25 年度 生態系サービスの定量的評価に関する調 査等業務報告書, $171 \mathrm{pp}$.

Franklin, J. 2010. Mapping Species Distributions: Spatial Inference and Prediction. 320pp. Cambridge University Press, Cambridge.

環境省・生物多様性総合評価検討委員会. 2010. 生物 多様性総合評価報告書, $238 \mathrm{pp}$.

Kareiva, P., Tallis, H., Taylor, H. R., Gretchen, C. D. and Stephen, P. 2012. Natural Capital - Theory \& Practice of Mapping Ecosystem Services. 432pp. Oxford University Press, Oxford.

Secretariat of the Convention on Biological Diversity. 2010. Global Biodiversity Outlook 3. Montréal, 94 pp.

Secretariat of the Convention on Biological Diversity. 2014. Global Biodiversity Outlook 4. Montréal, 155 pp. 自然環境研究センター. 2012. 平成 23 年度生物多 様性評価の地図化に関する検討調査業務報告書, 253pp. 